\title{
Evaluating On-demand Irrigation Systems for Container-grown Woody Plants Grown in Biochar-amended Pine Bark
}

\author{
Nastaran Basiri Jahromi ${ }^{1}$ \\ Biosystems Engineering and Soil Science Department, University of \\ Tennessee, Knoxville, TN 37996
}

Amy Fulcher

Department of Plant Sciences, University of Tennessee, Knoxville, TN 37996

Forbes Walker

Biosystems Engineering and Soil Science Department, University of Tennessee, Knoxville, TN 37996

James Altland

U.S. Department of Agriculture, Application Technology Research Unit, Wooster, OH 44691

\section{Wesley Wright and Neal Eash \\ Biosystems Engineering and Soil Science Department, University of Tennessee, Knoxville, TN 37996}

Additional index words. automatic irrigation system, nursery crops, overhead irrigation, plantbased irrigation, substrate-based irrigation

\begin{abstract}
Controlling irrigation using timers or manually operated systems is the most common irrigation scheduling method in outdoor container production systems. Improving irrigation efficiency can be achieved by scheduling irrigation based on plant water needs and the appropriate use of sensors rather than relying on periodically adjusting irrigation volume based on perceived water needs. Substrate amendments such as biochar, a carbon (C)-rich by-product of pyrolysis or gasification, can increase the amount of available water and improve irrigation efficiency and plant growth. Previous work examined two on-demand irrigation schedules in controlled indoor (greenhouse) environments. The goal of this study was to evaluate the impact of these on-demand irrigation schedules and hardwood biochar on water use and biomass gain of containergrown Hydrangea paniculata 'Silver Dollar' in a typical outdoor nursery production environment. Eighteen independently controlled irrigation zones were designed to test three irrigation schedules on 'Silver Dollar' hydrangea grown in pine bark amended with $0 \%$ or $25 \%$ hardwood biochar. The three irrigation schedules were conventional irrigation and two on-demand schedules, which were based on substrate physical properties or plant physiology. Conventional irrigation delivered $1.8 \mathrm{~cm}$ water in one event each day. The scheduling of substrate-based irrigation was based on the soilless substrate moisture characteristic curve, applying water whenever the substrate water content corresponding to a substrate water potential of $-10 \mathrm{kPa}$ was reached. The plant-based irrigation schedule was based on a specific substrate moisture content derived from a previously defined relationship between substrate moisture content and photosynthetic rate, maintaining the volumetric water content (VWC) to support photosynthesis at $90 \%$ of the maximum predicted photosynthetic rate. Total water use for the substrate-based irrigation was the same as for the conventional system; the plant-based system used significantly less water. However, plant dry weight was $22 \%$ and $15 \%$ greater, water use efficiency (WUE) was $40 \%$ and $40 \%$ greater, and total leachate volume was $25 \%$ and $30 \%$ less for the substratebased and plant-based irrigation scheduling systems, respectively, than for conventional irrigation. The $25 \%$ biochar amendment rate reduced leachate volume per irrigation event, and leaching fraction, but did not affect total water use or plant dry weight. This research demonstrated that on-demand irrigation scheduling that is plant based or substrate based could be an effective approach to increase WUE for container-grown nursery crops without affecting plant growth negatively.
\end{abstract}

Overhead irrigation controlled by timers or manually operated systems is the most common method of irrigation for container
(Warsaw et al., 2009), which might cause an increase in crop vulnerability to disease (Chappell et al., 2013); a decrease in nursery crop growth resulting from human error (Belayneh et al., 2013; Million et al., 2007; Warsaw et al., 2009; Welsh and Zajicek, 1993); and/or an increase in leachate volume, which can cause an increase in nutrient losses. Improving irrigation efficiency can be achieved by scheduling irrigation with the appropriate use of sensors rather than by relying on periodically adjusting irrigation volume based on plant or substrate visual appearance (van Iersel et al., 2013). Overhead irrigation generally has an application efficiency (amount of water retained in the container/total water applied) of about $25 \%$ to $37 \%$ (Beeson and Knox, 1991), and a demand-based irrigation system reduced the overhead irrigation water loss by reducing the frequency of irrigation (Beeson, 2006).

Soil and substrate VWC measurement or use of models to predict crop water use can both be used as tools for plant-demand-based irrigation scheduling (e.g., Bauerle et al., 2002; Kim et al., 2011). Determining the correct substrate moisture content at which to irrigate can be done in one of two ways. The simplest method (hereafter called the substrate-based method) is to assume a range of plant-available water tensions, usually defined as $-1 \mathrm{kPa}$ and $-10 \mathrm{kPa}$ (ArguedasRodriguez, 2009), although this range can be extended beyond $-10 \mathrm{kPa}$ tension to achieve greater water savings (Fields et al., 2016). A more recently established method of predicting crop water use by plant physiological status (Cifre et al., 2005; Jones, 2004) can be based on the relationship between photosynthetic rate and substrate moisture content before the plant photosynthesis rate is reduced by water stress (Fulcher et al., 2012; Hagen et al., 2014; Nambuthiri et al., 2017). This method is hereafter referred to as the plant-based approach. Using either of these approaches, the on-demand irrigation systems schedule water application based on substrate moisture measurements.

In addition to examining the water and crop effects of irrigation scheduling techniques, this study also addressed the use of substrate amendments. Amendments such as biochar, a C-rich by-product of pyrolysis, can reduce substrate pore size by nesting between larger particles of pine bark and providing greater water-holding capacity. This reduction in substrate pore size has been demonstrated to increase the amount of available water and improve irrigation efficiency and plant growth (Caron et al., 2005). Biochar improves soil fertility in the long term by changing soil physiochemical properties and can act as a fertilizer itself (Glaser et al., 2002; Lehmann et al., 2006), because the concentration of nutrients in biochar products are greater than in the feedstock (raw material) (Altland and Boldt, 2018; Judd, 2016). Biochar products vary widely in mineral element concentration. The reason may be a result of the biochar being produced from a wide range of biomass material that may nursery production systems. Using a fixed irrigation rate in a timer-based or manual system can result in over- or underwatering 
affect the final product characteristics. Biochar products produced from different feedstocks can have different chemical properties even when using the same manufacturing process (Evans et al., 2017).

A previous study developed and evaluated two on-demand, need-based irrigation scheduling systems in two consecutive seasons in a greenhouse (Basiri Jahromi et al., 2017). These systems were based on plant physiology (plant based) and substrate physical properties (substrate based), as described earlier. The current study was an experiment established to validate the models in an outdoor production environment using more commonly used overhead irrigation system rather than the microirrigation used during the greenhouse experiment. The goal of this study was to evaluate the impact of ondemand irrigation scheduling and hardwood biochar amendment on plant water use and biomass gain of container-grown Hydrangea paniculata 'Silver Dollar' grown outdoors.

\section{Materials and Methods}

The experiment was initiated by filling 7.6-L plastic containers with aged pine bark amended with $0 \%$ or $25 \%$ biochar by volume. The biochar (Proton Power Inc., Lenoir City, $\mathrm{TN}$ ) was a mixed hardwood comprised of oak (Quercus spp.), hickory (Carya spp.), and yellow poplar (Liriodendron tulipifera) subjected to fast pyrolysis at $\approx 1000{ }^{\circ} \mathrm{C}$, with chemical and physical properties shown in Table 1. 'Silver Dollar' hydrangea rooted cuttings (Griffith Propagation Nursery Inc., Watkinsville, GA) were transplanted into the containers on 15 July 2016 and 5 May 2017.

The plants were top-dressed with controlledrelease fertilizer $(18 \mathrm{~N}-2.6 \mathrm{P}-9.9 \mathrm{~K})$ at a rate of $40 \mathrm{~g}$ per container (Osmocote Classic, Everris, Marysville, OH) 1 week after transplanting. A wetting agent (Aquagro L; Aquatrols, Paulsboro, NJ) was applied as a drench of $600 \mathrm{mg} \cdot \mathrm{L}^{-1}$ to ensure even wetting of the substrate. Plants were hand-watered until the roots reached the container sidewall. Just before initiating the experiment, the containers were soaked in water once to saturate the substrate evenly and then were drained to

Received for publication 9 Apr. 2018. Accepted for publication 31 Oct. 2018.

This project was supported by Agriculture and Food Research Initiative Competitive Award no. 2015-68007-23212 from the U.S. Department of Agriculture (USDA) National Institute of Food and Agriculture.

We acknowledge the USDA National Institute of Food and Agriculture for financial support; and Proton Power, Lenoir City, TN for the biochar source. We gratefully acknowledge Dr. Jim Owen, Dr. Jeb Fields, Dr. Grace Pietsch, Galina Melnichenko, Lori Osborne, and Melanie Stewart for their contributions; Dr. Arnold Saxton for statistical analysis; and Dr. Daniel Yoder and Magdalena Pancerz for their careful review, which greatly enhanced this manuscript.

${ }^{1}$ Corresponding author. E-mail: nbasirij@vols.utk. edu or basiri.nastaran@gmail.com. container capacity. Treatments were arranged in a $2 \times 3$ factorial with two substrates $(100 \%$ pine bark amended with biochar at $0 \%$ or $25 \%$ by volume) and three irrigation schedules (conventional, substrate-based, and plant-based irrigation). The experiment was arranged in a randomized complete block design with three replications and three subsamples in the 2016 experiment, and eight subsamples in the 2017 experiment. All data were analyzed using mixedmodels analysis of variance (SAS v9.4; SAS Institute, Cary, NC). Data acquired in both years was pooled because early analysis found no significant effect of experimental year on the measurements.

Substrate physical properties were determined for each substrate using a $15-\mathrm{cm}$-tall porometer (volume, $694 \mathrm{~cm}^{3}$ ), according to Fonteno and Harden (2010), with three replications for each container (Table 2). In addition, particle size distribution was determined for three replications of each substrate by passing the substrate through seven sieves $(6.30,2.00,0.71,0.50,0.25$, and 0.11 $\mathrm{mm}$ openings) and a lower catch pan shaken for 5 min with a Ro-Tap shaker (Rx-29; W.S. Tyler, Mentor, $\mathrm{OH}$ ).

Outdoor experiments were initiated on 15 Aug. 2016 and 15 June 2017 at the University of Tennessee, Knoxville, TN. Square irrigation zones of $135 \mathrm{~cm}$ by $135 \mathrm{~cm}$ were delineated by a grid of 1.9-cm-diameter PVC pipe with $220-\mathrm{cm}$ spacing between irrigation zones. Irrigation was applied to each zone by four overlapping sprinklers, each providing $5.5 \mathrm{~L} \cdot \mathrm{h}^{-1}$ (Toro ${ }^{\circledR} 570 \mathrm{Shrub}$ Spray; The Toro Co., Riverside, CA). The sprinklers were installed on 1.3-cm-diameter risers at a height of $66 \mathrm{~cm}$ above ground level. Each zone used a single irrigation scheduling technique. Because the irrigation system was replicated as well, three replicate primary containers for a specific irrigation-by-biochar treatment were placed in the center of the zone. In the 2017 study, these were augmented by an additional five supplementary containers not used for the water measurements but used for the biomass estimates. In 2017, these were in turn surrounded by an additional eight border containers to minimize edge effects. Because each zone represented a single replicate of a unique irrigation-by-biochar treatment combination, and there were three zone replicates, there were a total of 18 irrigation zones.

The control irrigation treatment was traditional delivering of $1.8 \mathrm{~cm}$ water in one daily application. The on-demand substratebased irrigation treatment was based on soilless substrate moisture characteristic curves developed using the evaporative method and the Hyprop system (UMS, Munich, Germany) (Basiri Jahromi et al., 2017). The lower set points (for irrigation to be actuated) corresponded to the $-10 \mathrm{kPa}$ tension; the upper set points (for irrigation to be turned off) corresponded to $-1 \mathrm{kPa}$ tension. The lower set points corresponded to VWC values of 0.37 and $0.34 \mathrm{~cm}^{3} \cdot \mathrm{cm}^{-3}$ for the $0 \%$ and $25 \%$ biochar amendment treatments, respectively; the upper set points corresponded to
0.46 and $0.49 \mathrm{~cm}^{3} \cdot \mathrm{cm}^{-3}$ for the $0 \%$ and $25 \%$ biochar treatments, respectively.

For the plant-based irrigation system, set points were developed based on a relationship developed in a previous study (Basiri Jahromi et al., 2017) between substrate moisture content and photosynthetic rate of 'Silver Dollar' hydrangea plants, characterized by a three-parameter sigmoidal curve (SigmaPlot v. 14, San Jose, CA) based on five replicates. The lower set point was the VWC expected to maintain photosynthesis at $90 \%$ of the predicted maximum photosynthetic rate, resulting in 0.25 and $0.36 \mathrm{~cm}^{3} \cdot \mathrm{cm}^{-3}$ for the $0 \%$ and $25 \%$ biochar rate, respectively. The upper set point for this method was the effective container capacity, defined as the VWC after substrate saturation and drainage of gravitational water but before evaporation losses occurred (Hagen et al., 2014). Effective container capacity values were 0.46 and $0.58 \mathrm{~cm}^{3} \cdot \mathrm{cm}^{-3}$ for the $0 \%$ and $25 \%$ biochar rate, respectively.

Substrate moisture levels within an irrigation zone were monitored with a moisture sensor in each of three containers as described previously. Sensors were installed so that the bottom of each probe was $7.6 \mathrm{~cm}$ below the substrate surface. There were no sensors in the five supplementary or eight border containers in the 2017 study. The moisture sensors (GS1; Meter Group Inc., Pullman, WA) were connected to a data logger (CR1000; Campbell Scientific Inc., Logan, UT) via a multiplexer (AM16/32, Campbell Scientific Inc.). Each moisture sensor was calibrated for its substrate type at three moisture levels to determine VWC. Two 16-channel relay controllers (SDM-CD16AC, Campbell Scientific Inc.) were used to operate solenoid valves controlling irrigation for each zone. A rain gauge was wired to the data logger to measure local precipitation, allowing irrigation scheduling to take natural rainfall into account.

There were three sensors per irrigation zone. For the two on-demand irrigation systems, when the average VWC estimated by the three sensors in a zone decreased to less than the lower set point, the data logger opened the valve controlling irrigation to all containers in that zone. The irrigation "on"

Table 1. Chemical and physical properties of the hardwood biochar used as a substrate amendment for container nursery production.

\begin{tabular}{lcr}
\hline Parameter & Units & Value \\
\hline Chemical properties & & \\
pH & & 10.5 \\
Electrical conductivity & $\mathrm{dS} \cdot \mathrm{m}^{-1}$ & 4.6 \\
Carbon & $\%$ & 88.6 \\
Nitrate & $\mathrm{mg} \cdot \mathrm{kg}^{-1}$ & 0.8 \\
Ammonia & $\mathrm{mg} \cdot \mathrm{kg}^{-1}$ & 14.5 \\
Phosphorus & $\%$ & 0.1 \\
Potassium & $\%$ & 0.5 \\
Physical properties & & \\
Bulk density & $\mathrm{g} \cdot \mathrm{cm}^{-1}$ & 0.1 \\
Surface area & $\mathrm{m}^{2} \cdot \mathrm{g}^{-1}$ & 366 \\
\hline
\end{tabular}

The results shown here were obtained from Control Laboratories, Watsonville, CA. 
Table 2. Physical properties of pine bark substrate amended with $0 \%$ or $25 \%$ by volume of hardwood biochar $(\mathrm{n}=3)$.

\begin{tabular}{|c|c|c|c|c|c|c|c|}
\hline \multirow[b]{2}{*}{$\begin{array}{l}\text { Biochar rate } \\
(\%)\end{array}$} & \multirow[b]{2}{*}{$\begin{array}{c}\text { Container capacity } \\
(\%)\end{array}$} & \multirow[b]{2}{*}{$\begin{array}{c}\text { Air space } \\
(\%)\end{array}$} & \multirow[b]{2}{*}{$\begin{array}{c}\text { Total porosity } \\
\text { (\%) }\end{array}$} & \multirow[b]{2}{*}{$\begin{array}{l}\text { Bulk density } \\
\quad\left(\mathrm{g} \cdot \mathrm{cm}^{-3}\right)\end{array}$} & \multicolumn{3}{|c|}{ Particle size distribution (\%) } \\
\hline & & & & & $\begin{array}{l}\text { Coarse } \\
(>2 \mathrm{~mm})\end{array}$ & $\begin{array}{c}\text { Medium } \\
(0.71-2 \mathrm{~mm})\end{array}$ & $\begin{array}{c}\text { Fine } \\
(<0.71 \mathrm{~mm})\end{array}$ \\
\hline$\overline{0}$ & $57.1 b^{z}$ & $30.0 \mathrm{a}$ & $87.1 \mathrm{a}$ & $0.24 \mathrm{a}$ & $52.1 \mathrm{a}$ & $29.4 \mathrm{a}$ & $18.5 \mathrm{~b}$ \\
\hline 25 & $65.7 \mathrm{a}$ & $20.4 \mathrm{~b}$ & $86.2 \mathrm{~b}$ & $0.22 \mathrm{~b}$ & $32.0 \mathrm{~b}$ & $31.7 \mathrm{a}$ & $36.3 \mathrm{a}$ \\
\hline$P$ value & 0.0008 & 0.0002 & 0.0213 & 0.0395 & 0.0242 & 0.0958 & 0.0274 \\
\hline
\end{tabular}

${ }^{\mathrm{z}}$ Means within a column followed by the same letter are not significantly different $(\alpha=0.05)$.

Substrate physical properties were determined using a 15-cm-tall porometer, according to the methods described by Fonteno and Harden (2010).

time for the zone was calculated individually based on the difference between the lower and upper set points and the flow rate for that zone.

Leachate volume was measured daily 1 to $2 \mathrm{~h}$ after each irrigation event for the three containers in the zone with probes. The leachate collection pans were shielded from the overhead irrigation by an inverted 7.6-L plastic container with the bottom removed. Leaching fraction was calculated as $[100 \times$ leachate volume $(\mathrm{mL}) /$ total irrigation volume $(\mathrm{mL})]$

At the beginning (15 Aug. 2016 and 15 June 2017) and end (25 Oct. 2016 and 25 Sept. 2017) of each experiment, substrate nutrient samples were collected using the pour-through extraction method (LeBude and Bilderback, 2009) from the three pots with probes in each zone. Samples were filtered with a $0.45-\mu \mathrm{m}$ syringe filter and then analyzed on an ICS 1100 (Ion Chromatography System; Dionex, Bannockburn, IL) for concentrations of nitrate $\left(\mathrm{NO}_{3}\right)$, phosphate $\left(\mathrm{PO}_{4}\right)$, and potassium $(\mathrm{K})$. Electrical conductivity (EC) was measured with a portable EC meter (HI 9811-5; Hanna Instruments, Smithfield, RI), and $\mathrm{pH}$ was measured with a benchtop $\mathrm{pH}$ meter (Denver Instrument, Bohemia, NY).

More measurements were taken during the 2017 experiment. This included plant size index [(plant width $1+$ plant width perpendicular to width $1+$ plant height $) / 3$ ] for all the plants at initiation and termination of the experiment. Leaf chlorophyll content was measured using a soil-plant analysis development (SPAD) chlorophyll meter (SPAD502Plus; Konica Minolta, Tokyo, Japan), taking a measurement on the most recent fully developed leaves of three plants per pot and recording the mean for the three primary pots in each zone. Shoots and leaves were harvested and hand-washed at initiation (from identically treated extra plants) and at termination of the experiment, and dried at $55^{\circ} \mathrm{C}$ for $72 \mathrm{~h}$. The dried material of three plants of each zone was ground using a Wiley Mill (Thomas Scientific, Swedesboro, NJ). Plant tissue nitrogen $(\mathrm{N})$ was determined using a combustion CHNS/O analyzer (CE Elantech, Lakewood, NJ) from the three primary plants in each zone. Plant tissue used for analysis was prepared by acid digestion using concentrated nitric acid and analyzed by inductively coupled plasma-optical emission spectrometry for phosphorus (P), potassium, calcium $(\mathrm{Ca})$, and magnesium $(\mathrm{Mg})$ concentrations. WUE for each plant was calculated as [increase in dry weight $(\mathrm{g}) /$ total water applied (L)] for all measured plants in each zone.

\section{Results and Discussion}

Substrate physical properties. Container capacity increased whereas air space, total porosity, and bulk density decreased with application of $25 \%$ biochar to pine bark substrate (Table 2). Physical properties of pine bark substrate amended with $0 \%$ or $25 \%$ biochar were in the range recommended by Bilderback et al. (2013). Biochar addition also decreased the percentage of coarse particles by $39 \%$ and increased the percentage of fine particles by $96 \%$ (Table 2). Biochar application may improve water relations by increasing the container capacity, changing particle size distribution, and rearranging the substrate structure. Pine bark has a high pore space and low water-holding capacity because of the large macropores that cannot hold water as a result of low matric potential, whereas biochar has a high surface area that allows the substrate to hold a greater quantity of water. Soilless substrate water retention characteristics can be affected by pore size and number (Handreck and Black, 2002). Biochar application alters pore characteristics by nesting within the larger pores of pine bark and increasing the portion of the finer particle size and smaller pores, which causes an increase in container capacity and a decrease in the air space and total porosity. Increased container capacity and a reduction in air space were reported in other studies after biochar application to soilless substrates (Altland and Locke, 2017; Vaughn et al., 2013).

The bulk density of a composite material can be predicted by the weighted average of the substrate component's bulk density (Altland and Locke, 2013; Pokorny et al., 1986). Therefore, the reduction of bulk density in the $25 \%$ biochar amendment rate is a result of the addition of biochar, which is a lower density material $\left(0.10 \mathrm{~g} \cdot \mathrm{cm}^{-3}\right) \mathrm{com}$ pared with the pine bark substrate $\left(0.24 \mathrm{~g} \cdot \mathrm{cm}^{-3}\right)$. Reduction in bulk density was reported in other studies after biochar application to soilless substrates (Altland and Locke, 2012; Beck et al., 2011; Dumroese et al., 2011; Tian et al., 2012).

Irrigation scheduling systems. The upper and lower set points of the substrate-based irrigation system were predicated on the generally accepted range of plant-available water occurring between $-1 \mathrm{kPa}$ and $-10 \mathrm{kPa}$ tension (de Boodt and Verdonck, 1972). Irrigation was actuated when the average sensor reading fell to less than the VWC corresponding to a substrate water potential of $-10 \mathrm{kPa}$, generally considered the greatest tension for plant-available water. Plant-based irrigation was developed with the hypothesis that by maintaining VWC that corresponds to a predicted maximum photosynthetic rate at $90 \%$ or greater of the maximum photosyn- thetic rate, growth would not be reduced and substantial water savings could be achieved. Ninety percent of the maximum photosynthetic rate was observed at a greater VWC in the $25 \%$ biochar treatment $\left(0.36 \mathrm{~cm}^{3} \cdot \mathrm{cm}^{-3}\right) \mathrm{com}$ pared with the $0 \%$ biochar rate $\left(0.25 \mathrm{~cm}^{3} \cdot \mathrm{cm}^{-3}\right)$. Substrates with the $25 \%$ biochar rate had a greater VWC $\left(0.49 \mathrm{~cm}^{3} \cdot \mathrm{cm}^{-3}\right)$ at a lower tension $(-1 \mathrm{kPa})$ and less VWC $\left(0.34 \mathrm{~cm}^{3} \cdot \mathrm{cm}^{-3}\right)$ at a greater tension $(-10 \mathrm{kPa})$ compared with those with $0 \%$ biochar. Therefore, biochar application increased the plant-available water, which is defined as the VWC between $-1 \mathrm{kPa}$ and $-10 \mathrm{kPa}$. An increase in available water after biochar application was also reported by Rogovska et al. (2014).

Total water use, final dry weight, final size index, and WUE. Rainfall was well distributed during the 2017 experiment, but there were dry periods in 2016. Total rainfall for the experiment time frame was $70 \mathrm{~mm}$ in 2016 and $370 \mathrm{~mm}$ in 2017. There was no significant effect of biochar amendment rate nor any significant interaction between biochar rate and irrigation system for the measured parameters of total irrigation applied, final dry weight, final size index, WUE, or total leachate volume $(P>0.05)$.

Plant-based irrigation used significantly less water than the two other irrigation systems while still supplying the plants with sufficient water. The total amount of water used over the experiment was reduced by $16 \%$ using this system compared with the conventional system (Table 3). However, there was no difference in the total water use between conventional irrigation and the system based on substrate physical properties.

Although the total water use was unaffected or less in the two on-demand irrigation systems, plant dry weight $(P=0.0272)$ and size index $(P=0.0324)$ were greater in ondemand irrigation systems compared with the traditional industry practice of applying 1.8 $\mathrm{cm}$ water/d (Table 3). Plant dry weight was $22 \%$ and $15 \%$ greater, and size index was $9 \%$ and $6 \%$ greater in substrate-based and plant-based irrigation scheduling systems, respectively, compared with conventional irrigation. One reason might be that the on-demand irrigation system prevented the over- or underwatering that typically occurs with traditional nonsensor irrigation systems (Warren and Bilderback, 2005) that has been demonstrated to decrease nursery crop growth (Belayneh et al., 2013; Million et al., 2007; Warsaw et al., 2009; Welsh and Zajicek, 1993). Another reason might be that ondemand irrigation scheduling shortens the periods of low VWC between irrigation 
events, which may affect plant growth. The moisture deficit in traditional irrigation systems might approach or exceed the water buffering capacity, which results in little to no plant-available water (Nambuthiri et al., 2017). This appears to contradict the results of Warsaw et al. (2009) somewhat, who found that even moderate moisture deficit had little to no effect on plant growth. However, that research was conducted in a northern location with lower evapotranspiration crop demand.

The set point $\left(0.25 \mathrm{~cm}^{3} \cdot \mathrm{cm}^{-3}\right)$ in the $0 \%$ biochar rate with plant-based irrigation scheduling went beyond the water buffering capacity $(-5$ to $-10 \mathrm{kPa})$, resulting in water savings and greater plant biomass metrics, which suggests the range of plant-available water can be extended beyond $-10 \mathrm{kPa}$ tension, and range of plant-available water potential can be different in different substrates. Similar to our results, other recent studies reported an extended range of plantavailable water potential (Fields et al., 2017; Montesano et al., 2018) and also that the range of plant-available water potential may be somewhat dynamic as a result of a plant species and substrate effect on hydraulic conductivity (Fields et al., 2018; O'Meara et al., 2014).

Our results are consistent with other published studies that reported scheduling irrigation based on substrate water status or crop water requirements reduced water use without negative effects on plant growth and quality in comparison with conventional nursery irrigation systems (Basiri Jahromi et al., 2017; Grant et al., 2009; Incrocci et al., 2014; Stoochnoff et al., 2018; Warsaw et al., 2009). An increase or no changes in plant growth after biochar application was reported in different studies during container production (Dumroese et al., 2011; Graber et al., 2010; Headlee et al., 2014; Vaughn et al., 2013).

WUE was greater in the two on-demand irrigation schedules $(P=0.0442)$. It increased by $40 \%$ in both on-demand irrigation schedules compared with conventional irrigation (Table 3). Irrigation schedules increased WUE over the traditional industry practice of applying $1.8 \mathrm{~cm} / \mathrm{d}$ by applying the appropriate amount of water based on plant needs. Similar results have been reported in other studies (Beeson et al., 2004; Regan, 1999; van Iersel et al., 2013). Nambuthiri et al. (2017) reported that the moderate moisture deficit created by on-demand irrigation systems improved WUE by reducing the water use and leachate volume without a negative effect on plant growth. A plant-based irrigation schedule improved irrigation efficiency in Hibiscus rosa-sinensis 'Cashmere Wind', oakleaf hydrangea (Hydrangea quercifolia 'Alice'), and slender deutzia (Deutzia gracilis) (Fulcher et al., 2012; Hagen et al., 2014; Nambuthiri et al., 2017).

This outdoor experiment was intended to validate the water use models and greenhouse experiments (Basiri Jahromi et al., 2017) in an outdoor production environment using an overhead irrigation system. The results showed that on-demand irrigation schedules performed even better outside compared with the greenhouse experiments. On-demand irrigation scheduling improved plant biomass metrics and WUE when used outdoors. However, there were no differences in plant biomass metrics or WUE with on-demand irrigation compared with conventional irrigation in the greenhouse experiments (Basiri Jahromi et al., 2017).

Total leachate volume, leachate volume per irrigation event, and leaching fraction. Total leachate volume was $25 \%$ less in substrate-based and 30\% less in plant-based irrigation scheduling compared with the conventional irrigation system (Table 3 ). The substrate-based and conventional irrigation systems used the same amount of water, but the conventional irrigation system had a greater leachate volume. Both on-demand schedules may prevent the substrate from becoming hydrophobic by minimizing the length of time a substrate dries between irrigation events (Nambuthiri et al., 2017), reducing channeling of water and thus leachate volume and associated fertilizer leaching (Hoskins et al., 2014). The tendency of water to channel through the substrate increases when applied to the dry substrate (Hoskins et al., 2014). Similarly, Fulcher et al. (2012) reported that estimating plant water use using sensors tied to the physiological status of the plant can conserve water and minimize leachate.

Total water applied and total leachate volume were unaffected by the biochar amendment rate $(P>0.05)$ (Table 3$)$. However, leachate volume per irrigation event $(P=0.0038)$ and leaching fraction $(P=0.0001)$ were less in the $25 \%$ biochar-amended substrates (Table 4). Leachate volume was reduced by $16 \%$ and leaching fraction was reduced by $26 \%$ in the $25 \%$ biochar rate compared with the $0 \%$ biochar treatment. Leaching fraction was greater than the recommended guideline of $15 \%$ for all treatments (Bilderback et al., 2013). Previous greenhouse studies showed a reduction of leachate volume per irrigation event as a result of $25 \%$ biochar application to pine bark substrate (Basiri Jahromi et al., 2016, 2018).

Substrate solution and foliar nutrient analysis. Substrate solution $\mathrm{pH}$ was unaffected by irrigation system $(P>0.05)$, but was affected by biochar application $(P=$ 0.0009 ) (Table 4). Substrate $\mathrm{pH}$ was greater in the $25 \%$ biochar application rate (Table 4 ) because of the high $\mathrm{pH}(\mathrm{pH} 10.5)$ of the biochar (Table 1). Biochar $(\mathrm{pH}=10.5)$ application has been reported to increase soilless substrate $\mathrm{pH}$ in tomato (Solanum lycopersicum L.) and geranium (Pelargonium $\times$ hortorum) plants grown in a biocharamended peatmoss-based substrate (Altland and Locke, 2017). An increase in $\mathrm{pH}$ was also reported in biochar $(\mathrm{pH}=10.7)$-amended peat (Conversa et al., 2015) and biochar $(\mathrm{pH}=7.5)$-amended pine bark (Kaudal

Table 3. Total irrigation applied per container, final dry weight, final size index, water use efficiency $(\mathrm{n}=8)$, and total leachate volume ( $\mathrm{n}=3)$ for Hydrangea paniculata 'Silver Dollar' plants in substrates amended with $0 \%$ or $25 \%$ by volume of hardwood biochar.

\begin{tabular}{lccccc}
\hline Irrigation system & $\begin{array}{c}\text { Total irrigation applied } \\
\text { per container }(\mathrm{L})\end{array}$ & Final dry wt $(\mathrm{g})$ & Final size index $(\mathrm{cm})$ & Water use efficiency $\left(\mathrm{g} \cdot \mathrm{L}^{-1}\right)$ & Total leachate volume $(\mathrm{L})$ \\
\hline Conventional & $48.8 \mathrm{a}^{\mathrm{z}}$ & $96.9 \mathrm{~b}$ & $55.7 \mathrm{~b}$ & $1.0 \mathrm{~b}$ & $2.2 \mathrm{a}$ \\
Substrate based & $47.9 \mathrm{a}$ & $117.9 \mathrm{a}$ & $60.6 \mathrm{a}$ & $1.4 \mathrm{a}$ & $1.4 \mathrm{a}$ \\
Plant based & $40.8 \mathrm{~b}$ & $111.5 \mathrm{a}$ & $59.2 \mathrm{a}$ & & $16.6 \mathrm{~b}$ \\
$P$ value & & & & 0.0442 & \\
$\quad$ Irrigation & 0.0007 & 0.0272 & 0.0324 & 0.5545 & 0.0004 \\
$\quad$ Biochar & 0.1130 & 0.4643 & 0.7023 & $\mathrm{~b}$ & \\
\hline
\end{tabular}

${ }^{\mathrm{z}}$ Means in each column followed by the same letter were not significantly different $(\alpha=0.05)$.

Total irrigation applied and total leachate volume were measured both in 2016 and 2017. Data presented in this table are the average of both years. Final dry weight, final size index, and water use efficiency were measured in 2017 only.

Table 4. Leachate volume per irrigation event, total leachate volume, leaching fraction, substrate solution $\mathrm{pH}$, and electrical conductivity (EC) for Hydrangea paniculata 'Silver Dollar' plants in substrates amended with $0 \%$ or $25 \%$ by volume of hardwood biochar over 13 weeks $(n=3)$.

\begin{tabular}{lccccc}
\hline Biochar rate $(\%)$ & Leachate volume & & & \\
per irrigation event $(\mathrm{mL})$ & Total leachate volume $(\mathrm{L})$ & Leaching fraction $(\%)$ & $\mathrm{pH}$ & $\mathrm{EC}\left(\mathrm{dS} \cdot \mathrm{m}^{-1}\right)$ \\
\hline 0 & $298.4 \mathrm{a}^{\mathrm{z}}$ & $18.6^{\mathrm{NS}}$ & $51.9 \mathrm{a}$ & $6.2 \mathrm{~b}$ & $0.5^{\mathrm{NS}}$ \\
25 & $249.9 \mathrm{~b}$ & 17.6 & $38.2 \mathrm{~b}$ & $6.6 \mathrm{a}$ & 0.6 \\
$P$ value & 0.0038 & 0.4211 & 0.0001 & 0.0009 & 0.0909 \\
\hline
\end{tabular}

${ }^{\mathrm{z}}$ Means in same column followed by the same letter are not significantly different $(\alpha=0.05)$.

NS, Not significantly different $(\alpha=0.05)$.

Values presented in this table were measured in both 2016 and 2017 and are the average of both years. 
Table 5. Hydrangea paniculata 'Silver Dollar' substrate solution potassium $(\mathrm{K})$, nitrate $\left(\mathrm{NO}_{3}\right)$, phosphate $\left(\mathrm{PO}_{4}\right)$, calcium $(\mathrm{Ca})$ and magnesium $(\mathrm{Mg})$ concentration in a pine bark substrate amended with $0 \%$ or $25 \%$ by volume of hardwood biochar $(n=3)$ and a controlled release fertilizer (Osmocote $18 \mathrm{~N}-2.6 \mathrm{P}-$ $9.9 \mathrm{~K}$ at $40 \mathrm{~g}$ per container).

\begin{tabular}{lccccc}
\hline Biochar rate $(\%)$ & $\mathrm{NO}_{3}\left(\mathrm{mg} \cdot \mathrm{L}^{-1}\right)$ & $\mathrm{PO}_{4}\left(\mathrm{mg} \cdot \mathrm{L}^{-1}\right)$ & $\mathrm{K}\left(\mathrm{mg} \cdot \mathrm{L}^{-1}\right)$ & $\mathrm{Ca}\left(\mathrm{mg} \cdot \mathrm{L}^{-1}\right)$ & $\mathrm{Mg}\left(\mathrm{mg} \cdot \mathrm{L}^{-1}\right)$ \\
\hline 0 & $81.2^{\mathrm{NS}}$ & $6.1^{\mathrm{NS}}$ & $41.3^{\mathrm{NS}}$ & $47.3^{\mathrm{NS}}$ & $14.4^{\mathrm{NS}}$ \\
25 & 87.2 & 4.7 & 43.4 & 44.2 & 10.9 \\
$P$ value & 0.1578 & 0.9782 & 0.8356 & 0.4450 & 0.1447 \\
\hline
\end{tabular}

Ns, Not significantly different $(\alpha=0.05)$.

Values presented in this table were measured in both 2016 and 2017 and are the average of both years Samples were collected at the end (15 June 2016 + 25 Sept. 2017) of the experiment using the pour-through extraction method.

Table 6. Foliar nitrogen $(\mathrm{N})$, chlorophyll (SPAD) readings, phosphorus $(\mathrm{P})$, calcium $(\mathrm{Ca})$, potassium $(\mathrm{K})$, and magnesium $(\mathrm{Mg})$ concentration of Hydrangea paniculata 'Silver Dollar' grown in a pine bark substrate amended with either $0 \%$ or $25 \%$ by volume of hardwood biochar $(\mathrm{n}=3)$ and a controlled release fertilizer (Osmocote $18 \mathrm{~N}-2.6 \mathrm{P}-9.9 \mathrm{~K}$ at $40 \mathrm{~g}$ per container).

\begin{tabular}{lllllll}
\hline Biochar rate $(\%)$ & $\mathrm{SPAD}$ & $\mathrm{N}(\%)$ & $\mathrm{P}(\%)$ & $\mathrm{K}(\%)$ & $\mathrm{Ca}(\%)$ & $\mathrm{Mg}(\%)$ \\
\hline 0 & $2.4^{\mathrm{NS}}$ & $2.4^{\mathrm{NS}}$ & $0.01^{\mathrm{NS}}$ & $0.04^{\mathrm{NS}}$ & $0.12^{\mathrm{NS}}$ & $0.01^{\mathrm{NS}}$ \\
25 & 2.5 & 2.5 & 0.01 & 0.03 & 0.13 & 0.01 \\
$P$ value & 0.6162 & 0.3704 & 0.2841 & 0.0608 & 0.0616 & 0.6809 \\
\hline
\end{tabular}

Ns, Not significantly different $(\alpha=0.05)$.

Values presented in this table were measured in 2017 only.

et al., 2016). Many biochars have a high $\mathrm{pH}$ (Headlee et al., 2014; Tian et al., 2012), which is a result of the temperatures at which they were produced. Increasing pyrolysis temperatures is known to increase biochar cation exchange capacity and $\mathrm{pH}$ (Zhang et al., 2017).

Substrate solution EC was unaffected by the biochar rate and the irrigation system $(P>0.05)$ (Table 4). EC was in the range of 0.5 to 1.0 $\mathrm{dS} \cdot \mathrm{m}^{-1}$, which is the recommended range for $\mathrm{EC}$ in container substrate via the pour-through extraction method (Bilderback et al., 2013). Substrate solution nutrient concentrations at the end of the experiment were unaffected by biochar rates or irrigation systems $(P>0.05)$ (Table 5). Incrocci et al. (2014) reported similar results, indicating that substrate water status and irrigation scheduling did not affect leachate nutrient concentrations, $\mathrm{EC}$, and $\mathrm{pH}$.

Foliar chlorophyll (SPAD) readings and plant tissue nutrient concentration were unaffected by biochar rates and the irrigation system $(P>0.05)$ (Table 6). Similar to our results, Rogovska et al. (2014) reported no effect of hardwood biochar on plant tissue $\mathrm{N}, \mathrm{K}$, and $\mathrm{Mg}$ concentrations. The results of a meta-analysis of 114 published studies showed that concentration of plant tissue $\mathrm{N}$ and $\mathrm{P}$ did not show any effect from biochar application (Biederman and Harpole, 2013). Because the effect of biochar depends on the type of feedstock, the pyrolysis conditions, and the ecosystem or cropping systems to which biochar is applied (Altland and Boldt, 2018; Sohi et al., 2009), different nutrient concentration can be reported after biochar application. Biochar chemical properties may vary with source material even with the same production techniques (Evans et al., 2017). Thus, biochar amendments could be produced and prescribed based on meeting the nutrient needs of a specific crop.

\section{Conclusion}

This study demonstrated that water savings were achieved in some on-demand irrigation scheduling regimes in outdoor en- vironments compared with the traditional practice of applying $1.8 \mathrm{~cm}$ water/d in all treatments. On-demand irrigation regimes have worked even better outside with sprinkler-applied water compared with an earlier greenhouse experiment with microirrigation. In our study, plant-based irrigation used less water than the two other irrigation systems while still meeting crop demand, which makes it the optimal irrigation scheduling system in this experiment. Both on-demand irrigation scheduling regimes had greater plant biomass metrics and WUE, and less leachate volume compared with conventional irrigation. The $25 \%$ biochar amendment rate also reduced the leachate volume per irrigation event and leaching fraction. This research demonstrated that on-demand irrigation scheduling with a plant-based or substrate-based irrigation regime could be an effective approach to increase WUE for container-grown nursery crops without affecting plant growth adversely. Nursery industry professionals should consider adopting plant-based ondemand irrigation systems to increase water savings or expand production using existing and/or limited water supplies.

\section{Literature Cited}

Altland, J.E. and J.C. Locke. 2012. Biochar affects macronutrient leaching from a soilless substrate. HortScience 47:1136-1140.

Altland, J.E. and J.C. Locke. 2013. Gasified rice hull biochar is a source of phosphorus and potassium for container-grown plants. J. Environ. Hort. 31:138-144.

Altland, J.E. and J.C. Locke. 2017. High rates of gasified rice hull biochar affect geranium and tomato growth in a soilless substrate. J. Plant Nutr. 5:1-13.

Altland, J.E. and J.K. Boldt. 2018. Influence of substrate physical properties on container weed germination. J. Environ. Hort. 36:1-6.

Arguedas-Rodriguez, F.R. 2009. Calibrating capacitance sensors to estimate water content, matric potential, and electrical conductivity in soilless substrates. University of Maryland, College Park, MS Thesis.
Basiri Jahromi, N., F. Walker, A. Fulcher, and J. Altland. 2016. Effect of biochar on nutrient release and retention in container crops. 2016 Proc. Southern Nursery Assoc. Research Conf. 61:174-180.

Basiri Jahromi, N., F. Walker, A. Fulcher, and J. Altland. 2017. Photosynthesis, growth, and water use of Hydrangea paniculata 'Silver Dollar' produced with different irrigation schedules and biochar substrate amendment. HortScience 52:S273-S274.

Basiri Jahromi, N., F. Walker, A. Fulcher, J. Altland, and W.C. Wright. 2018. Growth response, mineral nutrition, and water utilization of container-grown woody ornamentals grown in biochar-amended pine bark. HortScience 53:347-353.

Bauerle, W.L., C.J. Post, M.F. McLeod, J.B. Dudley, and J.E. Toler. 2002. Measurement and modeling of the transpiration of a temperate red maple container nursery. Agr. For. Meteorol. 114:45-57.

Beck, D.A., G.R. Johnson, and G.A. Spolek. 2011. Amending greenroof soil with biochar to affect runoff water quantity and quality. Environ. Pollut. 159:2111-2118.

Beeson, R.C., Jr. 2006. Relationship of plant growth and actual evapotranspiration to irrigation frequency based on management allowed deficits for container nursery stock. J. Amer. Soc. Hort. Sci. 131:140-148.

Beeson, R.C., M.A. Arnold, T.E. Bilderback, B. Bolusky, S. Chandler, H.M. Gramling, J.D. Lea-Cox, J.R. Harris, P.J. Klinger, H.M. Mathers, J.M. Ruter, and T.H. Yeager. 2004. Strategic vision of container nursery irrigation in the next ten years. J. Environ. Hort. 22:113-115.

Beeson, R.C. and G.W. Knox. 1991. Analysis of efficiency of overhead irrigation in container production. HortScience 26:848-850.

Belayneh, B.E., J.D. Lea-Cox, and E. Lichtenberg. 2013. Costs and benefits of implementing sensorcontrolled irrigation in a commercial pot-in-pot container nursery. HortTechnology 23:760-769.

Biederman, L.A. and W.S. Harpole. 2013. Biochar and its effects on plant productivity and nutrient cycling: A meta-analysis. Glob. Change Biol. Bioenergy 5:202-214.

Bilderback, T., C. Boyer, M. Chappell, G. Fain, D. Fare, C. Gilliam, B.E. Jackson, J. Lea-Cox, A.V. LeBude, A. Niemiera, J. Owen, J. Ruter, K. Tilt, S. Warren, S. White, T. Whitewell, R. Wright, and T. Yeager. 2013. Best management practices: Guide for producing nursery crops. 3rd ed. Southern Nursery Association, Acworth, GA

Caron, J., D.E. Elrick, R. Beeson, and J. Boudreau. 2005. Defining critical capillary rise properties for growing media in nurseries. Soil Sci. Soc. Amer. J. 69:794-806.

Chappell, M., S.K. Dove, M.W. van Iersel, P.A. Thomas, and J. Ruter. 2013. Implementation of wireless sensor networks for irrigation control in three container nurseries. HortTechnology 23:747-753.

Cifre, J., J. Bota, J.M. Escalona, H. Medrano, and J. Flexas. 2005. Physiological tools for irrigation scheduling in grapevine (Vitis vinifera L.). Agr. Ecosyst. Environ. 106:159-170.

Conversa, G., A. Bonasia, C. Lazzizera, and A. Elia. 2015. Influence of biochar, mycorrhizal inoculation, and fertilizer rate on growth and flowering of Pelargonium (Pelargonium zonale L.) plants. Front. Plant Sci. 6:429.

de Boodt, M. and O. Verdonck. 1972. The physical properties of substrates in horticulture. Acta Hort. 26:37-44.

Dumroese, R.K., J. Heiskanen, K. Englund, and A. Tervahauta. 2011. Pelleted biochar: Chemical 
and physical properties show potential use as a substrate in container nurseries. Biomass Bioenergy 35:2018-2027.

Evans, M.R., B.E. Jackson, M. Popp, and S. Sadaka. 2017. Chemical properties of biochar materials manufactured from agricultural products common to the Southeast United States. HortTechnology 27:16-23.

Fields, J.S., J.S. Owen, J.E. Altland, M.W. van Iersel, and B.E. Jackson. 2018. Soilless substrate hydrology can be engineered to influence plant water status for an ornamental containerized crop grown within optimal water potentials. J. Amer. Soc. Hort. Sci. 143:268-281.

Fields, J.S., J.S. Owen, and H.L. Scoggins. 2017. The influence of substrate hydraulic conductivity on plant water status of an ornamental container crop grown in suboptimal substrate water potentials. HortScience 52:1419-1428.

Fields, J.S., J.S. Owen, L. Zhang, and W.C. Fonteno. 2016. Use of the evaporative method for determination of soilless substrate moisture characteristic curves. Scientia Hort. 211:102109.

Fonteno, W.C. and C.T. Harden. 2010. North Carolina State University Horticultural Substrates Lab Manual. North Carolina State Univ., Raleigh, NC.

Fulcher, A., J.W. Buxton, and R.L. Geneve. 2012. Developing a physiological-based, on-demand irrigation system for container production. Scientia Hort. 138:221-226.

Glaser, B., J. Lehmann, and W. Zech. 2002. Ameliorating physical and chemical properties of highly weathered soils in the tropics with charcoal: A review. Biol. Fertil. Soils 35:219-230.

Graber, E.R., Y.M. Harel, M. Kolton, E. Cytryn, A. Silber, D.R. David, L. Tsechansky, M. Borenshtein, and Y. Elad. 2010. Biochar impact on development and productivity of pepper and tomato grown in fertigated soilless media. Plant Soil 337:481-496.

Grant, O.M., M.J. Davies, H. Longbottom, and C.J. Atkinson. 2009. Irrigation scheduling and irrigation systems: Optimising irrigation efficiency for container ornamental shrubs. Irrig. Sci. 27:139-153.

Hagen, E., S. Nambuthiri, A. Fulcher, and R. Geneve. 2014. Comparing substrate moisturebased daily water use and on-demand irrigation regimes for oakleaf hydrangea grown in two container sizes. Scientia Hort. 179:132-139.

Handreck, K. and N. Black. 2002. Growing media for ornamental plants and turf. 3rd ed. Univ. New South Wales Press, Sydney.

Headlee, W.L., C.E. Brewer, and R.B. Hall. 2014. Biochar as a substitute for vermiculite in potting mix for hybrid popular. Bioenergy Res. 7:120-131.

Hoskins, T.C., J.S. Owen, and A.X. Niemiera. 2014. Water movement through a pine-bark substrate during irrigation. HortScience 49: 1432-1436.

Incrocci, L., P. Marzialetti, G. Incrocci, A. Di Vita, J. Balendonck, C. Bibbiani, S. Spagnol, and A. Pardossi. 2014. Substrate water status and evapotranspiration irrigation scheduling in heterogenous container nursery crops. Agr. Water Mgt. 131:30-40.

Jones, H.G. 2004. Irrigation scheduling: Advantages and pitfalls of plant-based methods. J. Expt. Bot. 55:2427-2436.

Judd, L.A. 2016. Physical and chemical analyses of two biochars produced from pine wood chips and rice hulls and their effects on container substrates. North Carolina State Univ., Raleigh, NC, PhD Diss.

Kaudal, B.B., D. Chen, D.B. Madhavan, A. Downie, and A. Weatherley. 2016. An examination of physical and chemical properties of urban biochar for use as growing media substrate. Biomass Bioenergy 84:49-58.

Kim, J. and M.W. van Iersel. 2011. Slowlydeveloping drought stress increases photosynthetic acclimation of Catharanthus roseus. Physiol. Plant. 143:166-177.

LeBude, A.V. and T.E. Bilderback. 2009. Pour through extraction procedure: A nutrient management tool for nursery crops. North Carolina Coop. Ext. AG-717-W.

Lehmann, J., J. Gaunt, and M. Rondon. 2006. Biochar sequestration in terrestrial ecosystems: A review. Mitig. Adapt. Strat. Gl. 11:403-427.

Million, J., T. Yeager, and J. Albano. 2007. Consequences of excessive overhead irrigation on runoff during container production of sweet viburnum. J. Environ. Hort. 25:117-125.

Montesano, F.F., M.W. van Iersel, F. Boari, V. Cantore, G. D'Amato, and A. Parente. 2018. Sensor-based irrigation management of soilless basil using a new smart irrigation system: Effects of set-point on plant physiological responses and crop performance. Agr. Water Mgt. 203:20-29.

Nambuthiri, S., E. Hagen, A. Fulcher, and R. Geneve. 2017. Evaluating a physiologicalbased, on-demand irrigation system for containergrown woody plants with different water requirements. HortScience 52:251-257.

O'Meara, L., C.R. Matthew, and M.W. van Iersel. 2014. Water use of Hydrangea macrophylla and Gardenia jasminoides in response to a gradually drying substrate. HortScience 49:493-498.
Pokorny, F.A., P.G. Gibson, and M.G. Dunavent. 1986. Prediction of bulk density of pine bark and/or sand potting media from laboratory analyses of individual components. J. Amer. Soc. Hort. Sci. 111:8-11.

Regan, J.M. 1999. Nursery irrigation scheduling, p. 1-8. Proc. $2^{\text {nd }}$ Annu. Nursery Growers short course. Wilsonville, OR.

Rogovska, N., D.A. Laird, S.J. Rathke, and D.L. Karlen. 2014. Biochar impact on midwestern mollisols and maize nutrient availability. Geoderma 230-231:340-347.

Sohi, S., E. Lopez-Cape, E. Krull, and R. Bol. 2009. Biochar, climate change and soil: A review to guide future research. CSIRO Land and Water Science Report series.

Stoochnoff, J.A., T. Graham, and M.A. Dixon. 2018. Drip irrigation scheduling for container grown trees based on plant water status. Irrig. Sci. 36:179-186.

Tian, Y., X. Sun, S. Li, H. Wang, L. Wang, J. Cao, and L. Zhang. 2012. Biochar made from green waste as peat substitute in growth media for Calathea rotundifola cv. Fasciata. Scientia Hort. 143:15-18.

van Iersel, M.W., M. Chappell, and J.D. Lea-Cox. 2013. Sensors for improved efficiency of irrigation in greenhouse and nursery production. HortTechnology 23:735-746.

Vaughn, S.F., J.A. Kenar, A.R. Thompson, and S.C. Peterson. 2013. Comparison of biochars derived from wood pellets and pelletized wheat straw as replacements for peat in potting substrates. Ind. Crops Prod. 51:437-443.

Warren, S.L. and T.E. Bilderback. 2005. More plant per gallon: Getting more out of your water. Hort Technology 15:14-18.

Warsaw, A.L., R.T. Fernandez, B.M. Cregg, and J.A. Andresen. 2009. Water conservation, growth, and water use efficiency of containergrown woody ornamentals irrigated based on daily water use. HortScience 44:1308-1318.

Welsh, D.F. and J.M. Zajicek. 1993. A model for irrigation scheduling in container-grown nursery crops utilizing management allowed deficit (MAD). J. Environ. Hort. 11(3):115-118.

Zhang, A.F., Y.M. Liu, G.X. Pan, Q. Hussain, L.Q. Li, J.W. Zheng, and X.H. Zhang. 2011. Effect of biochar amendment on maize yield and greenhouse gas emissions from a soil organic carbon poor calcareous loamy soil from central China plain. Plant Soil 351:263-275.

Zhang, H., R.P. Voroney, and G.W. Price. 2017. Effects of temperature and activation on biochar chemical properties and their impact on ammonium, nitrate, and phosphate sorption. J. Environ. Qual. 46:889-896. 